DOI https://doi.org/10.30525/978-9934-26-111-4-37

\title{
ВИПАДКИ ВІДКЛАДЕНЬ НАЛИПАННЯ МОКРОГО СНІГУ КАТЕГОРІЇ НЯ (НЕБЕЗПЕЧНІ) ТА СГЯ (СТИХІЙНІ) НА ТЕРИТОРІЇ УКРАЇНИ ПРОТЯГОМ 2011-2020 РР.
}

\author{
Пясецька C. I. \\ кандидат географічних наук, \\ стариий науковий співробітник \\ Украӥнський гідрометеорологічний інститут \\ Державної служби Украӥни з надзвичайних ситуачій \\ та Національної академії наук України \\ м. Київ, Україна
}

Випадки налипання мокрого снігу відноситься до ожеледопаморозевих відкладень та є несприятливим погодним явищем для ряду погодозалежних від них ланок господарського комплексу, спричиняючи перешкоди у їх роботі. Особливо небезпечними у цьому сенсі $\epsilon$ відкладення налипання мокрого снігу з діаметрами 11-34 мм - категорії НЯ (небезпечна), а також більше 35 мм - категорії СГЯ (стихійна) [1]. Натепер критерії небезпеки викладено у оновленому Нормативному документі [2], де розширено кількісні позначення стану небезпеки та їх кольорове відображення у прогнозі що надається. Території країни, де найчастіше спостерігаються випадки відкладення налипання мокрого снігу, у тому числі небезпечних діаметрів утворюють кліматовразливі регіони від цього виду ожеледо-пеморозевих відкладень. Найбільш визначний внесок у визначення умов та просторового розподілу випадків різних видів ожеледо-паморозевих відкладень було зроблено O.М. Раєвським [3, 4] завдяки його дослідженням 3 типізації форм рельєфу стосовно їх розподілу в залежності від висоти місцевості та іiі територіальної організації. У подальшому це було використано у дослідженнях А.В. Рудневої наприкінці 50-х -60-х роках XX ст. відносно повторюваності, інтенсивності та просторово-часового розподілу ожеледо-паморозевих відкладень на теренах колишнього СРСР, зокрема відкладень налипання мокрого снігу [5]. Протягом 90 -х років - початку XXI ст. більш докладне дослідження випадків таких відкладень значних діаметрів на території України було здійснено у роботах під керівництвом В.М. Бабіченко [7, 8], де вказано на зростаючу кількість небезпечних випадків ожеледо-паморозевих відкладень, особливо налипання мокрого снігу. Зважаючи на різкі 
зміни погодних умов, що пов'язані із триваючою зміною клімату, постає нагальна потреба у продовженні моніторингу за такими відкладеннями та дослідження сучасного просторово-часового стану їх розповсюдження для забезпечення сталого розвитку держави.

Дослідження просторово-часового розподілу випадків відкладень налипання мокрого снігу категорії НЯ (небезпечна) та СГЯ (стихійна) було проведено для місяців холодного (листопад - березень) та окремих місяців (квітень, жовтень) перехідних сезонів року періоду останнього десятиріччя 2011-2020 pp.

Для випадків відкладень налипання мокрого снігу категорії НЯ (небезпечна) було встановлено, що загалом таких випадків спостерігалось 376. За кількістю та повторюваністю таких випадків виділяються зимові місяці - грудень - 87 (23,1 \%), січень - 86 (22,9 \%) та особливо лютий - 110 (29,3\%). У березні їх кількість становила 33 випадки, що склало 8,8 \% та 20 випадків у квітні (5,3\%). У жовтні їх кількість становила - 9 випадків, або 2,4 \%, проте у листопаді вона зросла до 31 (8,2 \%) та майже зрівнялась із березнем. Здебільшого такі випадки, принаймні у зимові місяці, спостерігаються кожного року за окремим виключенням, проте навесні та восени вони можуть спостерігатись в окремі роки та їх кількість значно виділятись за кількістю від року до року У січні 2011-2020 рр. за кількістю таких випадків найбільш виділяються 2012 (20,9 \%), 2015 (20,9 \%) та 2018 рр. $(14,0 \%)$. Територіально за повторюваністю таких випадків відкладень найбільш виділяються Закарпаття - 15,1 \%, Одещина - 9,3 \%, Харківщина та Чернігівщина по 8,1 \% кожна, а також Київщина - 7,0 \%. Випадки відкладень налипання мокрого снігу категорії НЯ не спостерігались на Рівненщині, Тернопільщині, Івано-Франківщині, Чернівеччині та Миколаївщині. У лютому за кількістю таких випадків виділяються 2013 (25,5 \%), 2015 (15,5\%), 2018 (10,9\%), 2019 (10,0 \%), 2020 (19,1 \%). Серед областей найбільшу повторюваність таких випадків мали Харківщина - 12,7 \%, Київщина $(10,0 \%)$, Чернігівщина $(9,1 \%)$, Черкащина (8,2 \%) Дніпропетровщина (7,2 \%). Випадки відкладень налипання мокрого снігу протягом 2011-2020 pр. не спостерігались на Львівщині, Миколаївщині та Херсонщині. У березні найбільше випадків відкладень мокрого снігу категорії НЯ спостерігалось у 2013 (42,4 \%) та 2015 (18,2 \%) pр. Найчастіше вони спостерігались на Харківщині (18,2 \%), Київщині та Сумщині (по 12,1 $\%$ кожна). Не спостерігались подібні відкладення на Волині, Рівненщині, Львівщині, Тернопільщині, Черкащині, Кіровоградщині, Дніпропетровщині, Миколаївщині та Криму. У квітні у ряді років 
(2011, 2013, 2014, 2018-2020) випадки відкладень мокрого снігу категорії НЯ не спостерігались, а їх найбільша кількість спостерігалась у 2017 р. (40,0 \%) та дещо менше у 2012 та 2015 рр. (по 25,0 \% кожний). По регіонах країни такі відкладення частіше спостерігались на Хмельниччині (15,0 \%), а також Івано-Франківщині, Чернівеччині, Сумщині та Харківщині (по 10,0 \% кожна). В середині осені у жовтні протягом 2011-2020 рр. випадки відкладень налипання мокрого снігу категорії НЯ були не численні, а у ряді років $(2011,2014,2017-2020)$ вони не спостерігались взагалі. Їх найбільша кількість спостерігалась у 2012 p. - 44,4 \%. Територіально вони частіше відмічались на Сумщині та Чернівеччині (по 22,2 \% у кожній). У листопаді відкладення частіше спостерігались у 2016 р (32,3 \%) та у 2017, 2018, 2020 pp. (по 16,1\% кожний). Територіально вони частіше відмічались на території Київщини та Харківщини (по 12,9 \% кожна), а також на Чернігівщині та Житомирщині (по 9,7 \% кожна). Не спостерігались такі відкладення на Волині, Рівненщині, Львівщині, Черкащині, Кіровоградщині, Дніпропетровщині, Одещині, Миколаївщині та Криму. У грудні випадки відкладень мокрого снігу категорії НЯ спостерігались кожного року 3 досліджуваного десятиріччя. Найбільша їх кількість спостерігалась у 2017 р (24,1\%), а також у 2018 (16,1\%) та 2011 (12,6\%), 2012 і 2015 рр. (13,8 \%). Найбільш часто випадки відкладень мокрого снігу спостерігались на Чернігівщині, Київщині та Закарпатті (по 13,8 \% у кожній), а також на Харківщині $(8,0$ \%) та Житомирщині $(6,9$ \%). Не спостерігалось їх на Рівненщині, Хмельниччині, Тернопільщині, Дніпропетровщині, Донеччині, Херсонщині.

Таким чином найбільш часто відкладення налипання мокрого снігу категорії НЯ протягом 2011-2020 рр. спостерігались у 2012 (січень, лютий), 2012 (жовтень), 2013 (лютий, березень), 2015 (січень, лютий), 2016 (листопад), 2017 (квітень, грудень). Територіально вони переважали на території північних та північно-східних областей (Київщина, Чернігівщина, Сумщина), а також в окремих регіонах на заході країни (Закарпаття, Хмельниччина, Чернівеччина).

Випадки відкладень налипання мокрого снігу категорії СГЯ (стихійна) спостерігались протягом 2011-2020 pр. на території України загальною кількістю 41 випадок. За кількістю таких відкладень виділяється грудень - 12 (29,3\%), січень - 7 (17,1 \%) та лютий 15 (36,6 \%). Навесні та восени таких відкладень було мало - у березні 1 випадок (2,4 \%), у квітні та листопаді - 3 випадки (по 7,3\%). У жовтні таких випадків на території України не спостерігалось. Випадки відкладень налипання мокрого снігу категорії СГЯ 
спостерігаються значно менше ніж такі відкладення категорії НЯ. У січні 2011-2020 pр. найбільша кількість випадків відкладень налипання мокрого снігу категорії СГЯ спостерігалась у 2017 (42,9 \%) та 2011 pp. (28,6 \%). У 2012-2014, 2016, 2019 та 2020 рр. випадків відкладень налипання мокрого снігу категорії СГЯ на території України не спостерігалось. Територіально такі відкладення відмічались на території 5 областей - Закарпатті Львівщині, Черкащині, Одещині, Запоріжжі. Найбільша їх повторюваність спостерігалась на Закарпатті та Львівщині (по 28,6 \% кожна). У лютому такі відкладення спостерігались дещо частіше ніж у січні за виключенням 2011, 2012, 2014, 2017 та 2020 рр. Їх найбільша кількість спостерігалась у 2013 р. $(60,0 \%)$, ще у 2015 р. їх було 3 (20,0 \%). По областях України подібні відкладення спостерігались на 103 них (Закарпаття, Чернівеччина. Івано-Франківщина, Чернігівщина, Сумщина, Житомирщина, Київщина, Харківщина, Вінниччина, Кіровоградщина). Найбільше таких відкладень припало на Київщину (26,7 \%), Харківщину та ІваноФранківщину (по 13,3 \% на кожну), на решту вищезгаданих областей по 6,7 \%. У березні періоду 2011-2020 р. випадок відкладення налипання мокрого снігу категорії СГЯ спостерігався лише на Київщині у 2013 р. У квітні досліджуваного періоду такі відкладення спостерігались лише у 2015 (66,7 \%) та 2017 pp. (33,3 \%). Вони спостерігались на Львівщині, Черкащині та Херсонщині. Внесок кожної з цих областей у загальну кількість був однаковим і становив по 33,3 \% кожна. У жовтні випадків відкладень налипання мокрого снігу категорії СГЯ на території України не спостерігалось. Протягом листопада подібні відкладення спостерігались лише у 2016 та 2017 pp. Найбільший внесок мав 2016 р. - 66,7 \% у загальну кількість за місяць. По території країни вони віммічались на Івано-Франківщині $(66,7$ \%) та на Хмельниччині $(33,3$ \%). У грудні найбільша кількість подібних випадків спостерігалась у 2015 (30,8 \%) та 2012 і 2018 pp. (по 23,1 \% на кожний), а на решті по 7,7 \%. У 2013,2014, 2019 та 2020 pp. їх не спостерігалось. Найбільша кількість таких випадків спостерігалась на Київщині $(38,5$ \%) та Харківщині (23,1%). Внесок Житомирщини, Львівщини, Черкащини та Миколаївщини склав 7,7 \% кожна.

Таким чином випадки відкладень налипання мокрого снігу категорії СГЯ протягом 2011-2020 рр. здебільшого спостерігались у лютому 2013 та грудні 2015 рр. переважно на заході та півночі (північному сході) України. 


\section{Література:}

1. Настанова по службі прогнозів та попереджень про небезпечні і стихійні явища погоди. Державна гідрометеорологічна служба. Київ, 2003. 30 с.

2. Настанова 3 метеорологічного прогнозування. Нормативний документ. УкрГМЦ. М. Київ. 2019. 35 с.

3. Раевский А.Н. Влияние особенностей рельефа на распределение гололедных отложений. Труды ГГО. 1961. Вып. 122. С. 45-52.

4. Раевский А.Н. Распределение редко повторяющихся отложений мокрого снега на территории УССР. Метеорология, климатология и гидрология. 1960. Вып. 16. С. 78-86.

5. Руднева А. В. Мокрый снег и облединение проводов на территории СССР. Л.: Гидрометеоиздат, 1964. 166 с.

6. Стихийные метеорологические явления на Украине и в Молдавии / Под ред. В.Н. Бабиченко. - Л.: Гидрометеоиздат, 1991. 223 с.

7. Стихійні метеорологічні явища на території України за останнє двадцятиріччя (1986-2005 рр.) / За ред. В. М. Ліпінського, В. І. Осадчого, В. М. Бабіченко. К.: Ніка- Центр, 2006. 311 с. 